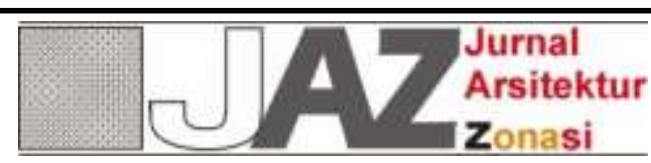

http://ejournal.upi.edu/index.php/jaz/ - e-mail: jurnal.zonasi@gmail.com dan jurnal_zonasi@upi.edu DOI: http://10.17509/jaz.v1i1.12216

\title{
Ruang Andangan Arsitektur Limasan Sebagai Wadah Tradisi Kalang Etnografi Demang Kalang (sub etnis Jawa)
}

\section{Article History:}

First draft received:

27 Juli 2018

Revised:

15 Agustus 2018

Accepted:

23 Agustus 2018

Final proof received:

Print:

27 Oktober 2018

Online

31 Oktober 2018

\section{Prabani Setiohastorahmanto ${ }^{1}$, Sugiono Soetomo ${ }^{2}$,} Agung Budi Sardjono ${ }^{3}$

${ }^{1}$ Mahasiswa Program Doktor Teknik Arsitektur dan Perkotaan, Universitas Diponegoro

Semarang.

${ }^{2,}$ Dosen Departemen Perencanaan Wilayah dan Kota, Fakultas Teknik, Universitas

Diponegoro, Semarang.

${ }^{3}$ Dosen Departemen Arsitektur, Fakultas Teknik, Universitas Diponegoro, Semarang.

Email: budipurnomo.s3@gmail.com sugiono.soetomo@pwk.undip.ac.id agungbs@arsitektur.undip.ac.id

Abstract: Sub ethnic group of Java until today still continue to carry out the tradition inherited by the ancestors. Although considered a curious tradition by some Java in General, but still continued to be carried out. The implementation of these traditions is the implementation of the philosophy of the Java space dark and light. Unmaterial cultural traditions is from the ethnic Javanese which is carried out in a traditional Javanese Limasan architecture the container. The Limasan architecture artifact is used as a container for carrying out the traditions of the philosophy of the Java space that becomes the reference implementation. The sub ethnic Javanese known as the Kalang. This research referred to as wong Kalang. In today's modern era, still encountered Javanese people who carry out the tradition of ancestral heritage in a cycle time of their lives. This tradition is an interesting thing to note with spatial dependenciesof Java. Obong tradition so they call it, is the responsibility of the family against family members who have died. Then the research questions: 1) The Limasan architecture does have a relationship with the tradition of the obong implemented wong Kalang?; 2) What meaning is Limasan architecture group wong Kalang? Through ethnographic techniques using qualitative research approach, will find few relationships and the meaning of tradition has the architectural space in the Kalang. The conclusion is: 1) The Limasan architecture space settings have corelation with the Kalang tradition; 2) Limasan Architecture have important meaning in the implementation of the overall tradition not only obong tradition.

Keywords: Andangan, Kalang, Limasan, Obong, Kiwo

Abstrak: Kelompok sub etnis Jawa, hingga saat ini masih terus melaksanakan tradisi yang diwarisi oleh leluhur. Meskipun dianggap tradisi yang aneh oleh sebagian orang Jawa, namun masih terus dilaksanakan. Pelaksanaan tradisi tersebut merupakan implementasi dari filosofi tata ruang Jawa ruang gelap dan ruang terang. Tradisi tersebut dilaksanakan dalam wadah arsitektur tradisional Jawa Limasan. Sub etnis Jawa tersebut dikenal dengan nama Kalang. dalam penelitian ini disebut sebagai wong Kalang. Tradisi obong begitulah mereka menyebutnya, merupakan tanggung jawab keluarga terhadap anggota keluarga yang telah meninggal. Pertanyaan penelitian: 1) Apakah arsitektur Limasan memiliki hubungan dengan tradisi obong yang dilaksanakan wong Kalang?; 2) Apa makna arsitektur Limasan bagi kelompok wong Kalang? Penelitian ini akan mengungkap makna arsitektur Limasan bagi wong Kalang. Melalui teknik etnografi dengan menggunakan pendekatan penelitian kualitatif, akan ditemukan beberapa hubungan dan makna dari pelaksanaan tradisi Kalang dalam ruang arsitektur Limasan. Dari hasil penelitian dapat disimpulkan bahwa: 1) Setting ruang arsitektur Limasan memiliki hubungan dengan tradisi Kalang; 2) Arsitektur Limasan, memiliki makna yang penting dalam terlaksananya tradisi Kalang secara keseluruhan bukan hanya tradisi obong.

Kata kunci: Andangan, Kalang, Limasan, obong, Kiwo. 


\section{Pendahuluan}

Arsitektur Jawa yang kita kenal melalui bentuk atap merupakan identitas Jawa yang memberikan keagungan dari bagian kepala (atap) sebagai mahkota yang melambangkan status dari penghuninya. Status tersebut akan merujuk pada suatu kehidupan sosial dan kemapanan ekonomi orang yang menghuni. Atap Joglo merupakan simbol dari kemapanan seorang bangsawan, atap Limasan menunjukan kemapanan penghuninya yang merupakan kelompok yang memiliki kemampuan sosial dan ekonomi berada dibawah bangsawan hingga strata ekonomi menengah, atap Kampung dan Panggang Pe, mewakili kelompok yang memiliki strata ekonomi menengah kebawah sering digunakan oleh para petani, nelayan, sedangkan atap Tajug yang sering digunakan untuk tempat ibadah (Dakung, 1982). Selain menunjukan status, atap sebagai pelindung aktivitas keseharian yang sifatnya domestik (Revianto, 2000). Dengan demikian terbentuklah suatu arsitektur tradisional Jawa, arsitektur yang dibangun melalui tradisi dan juga digunakan untuk melaksanakan tradisi. Jika ditinjau dari fungsinya, maka arsitektur Jawa memiliki fungsi. (Tjahjono, 1989). Kehidupan tradisi dalam rumah tradisional Jawa tentunya akan nampak pada saat pelaksanaan tradisi. Tradisi orang Jawa mencakup kehidupan yang menyeluruh sejak kehamilan hingga kematian (Muhammad, 2010). Tradisi tersebut secara turun-temurun dilaksanakan dengan penuh tanggung jawab dengan tujuan mulia menghargai para leluhur, memohon berkah agar tercapai keselamatan. Pelaksanaan tradisi Jawa yang masih ada saat ini menunjukan kepatuhan masyarakat Jawa. Kepatuhan tersebut menunjukan bahwa secara lahiriah orang Jawa menghargai sesama manusia dan menjaga toleransi. Sedangkan secara batiniah orang Jawa yang memiliki akar kepercayaan kejawen berusaha untuk mencapai kesempurnaan dalam hidup. Dua prinsip fundamental yang realitis dalam kehidupan orang Jawa (Suseno, 1984) Keserasian dan keharmonisan dalam kehidupan masyarakat Jawa merupakan suatu sikap yang terus diwarisi karena mengandung nilai-nilai yang mengatur kehidupan bersama. Sikap teposeliro (rukun, saling menghomati, dan peka terhadap lingkungan) merupakan wujud dari lahiriah orang Jawa. kehidupan Jawa yang kompleks dan banyak terjadi alkulturasi dengan budaya lain, namun akar teladan tetap ada dan terus diwarisi (Lombard, 2005). Sikap hidup orang Jawa dapat dilihat dari kehidupannya. Namun dalam lingkup tradisi Jawa menunjukan keberagaman yang harmonis dan menunjukan adanya cara pandang orang Jawa terhadap kepercayaan. Kepercayaan tersebut bukan muncul secara tiba-tiba namun melalui proses dari sistem nilai, tradisi dan menjadi budaya. Tradisi yang sudah umum dilakukan dianggap biasa, namun bagaimana jika orang Jawa tetapi melaksanakan tradisi yang berbeda? Tradisi ini terjadi pada suatu kelompok masyarakat yang merupakan sub etnis Jawa (Abdul, 2015) yang dikenal sebagai wong Kalang. Istilah wong merupakan bahasa Jawa yang berarti "orang". Penggunaan kata wong disini ingin menunjukan bahwa sub etnis yang dibahas adalah merupakan bagian dari kebudayaan Jawa. Kata Kalang menurut (Ranggawarsita, 2007) kamus bahasa Kawi-Jawa, Kalang dalam bahasa Jawa adalah Kajawi dan menurut kamus bahasa Jawa-Indonesia Kajawi berarti "selain". Jika kita melihat beberapa catatan sejarah mengenai wong Kalang diperkirakan telah ada sejak abad 8 yang telah tercatat dalam prasasti Harinjing (804 M) ditemukan di perkebunan Sukabumi desa Siman Kecamatan Kepung, Kediri, Jawa Timur. Prasasti ini terdiri dari: a) Prasasti Harinjing 25 Maret 804 Masehi; b) Prasasti Harinjing 19 September 921 Masehi; c) Prasasti Harinjing 7 Maret 927 Masehi. Tulisan dalam prasasti ini berbahasa Jawa kuno dan diterjemahkan oleh MM Soekarto Kartarmodjo, telah disebutkan Tuha Kalang yang diterjemahkan menjadi pemimpin golongan Kalang (mungkin tukang kayu atau pembuat bangunan) bernama Daman Wanua (Djulianto, 2017). Dengan demikian apakah kata Kalang ada hubungannya dengan arti secara harafiah atau hanya merupakan sebuah nama? Memang banyak istilah Kalang yang sering kita jumpai dalam tulisan mengenai Jawa. namun dalam tulisan ini akan membahas hasil penelitian tentang wong Kalang yang merupakan suatu kelompok sub etnis Jawa.

Kelompok wong Kalang saat ini menyebar diberbagai kota di pulau Jawa khususnya Jawa Tengah, Yogyakarta dan beberapa daerah perbatasan Jawa Tengah dengan Jawa timur. Beberapa kelompok wong Kalang masih dapat ditemukan melaksanakan aktivitas tradisi. Beberapa daerah yang 
masih ditemukan kelompok wong Kalang antara lain di Yogyakarta, Gunung Kidul, Solo, Kebumen, Gombong, Cilacap, Kendal, Cepu, bojonegoro. Dari penyebaran tersebut, mereka memiliki kesamaan dalam hal tradisi. Tradisi tersebut mereka terima secara turun-temurun yaitu tradisi Ewuh, tradisi obong dan tradisi Nyadran. Dari tiga tradisi tersebut, tradisi Obong merupakan tradisi yang memiliki ritual yang dapat dilihat karena berada di ruang terbuka dan menggunakan api sebagai aktivitas ritualnya. Tradisi Obong ini tujuannya mengantarkan arwah keluarga yang telah meninggal menuju tujuan akhir yaitu nirwana. Masih aktifnya tradisi ini karena adanya transfer pengetahuan tradisional yang dilakukan melalui tradisi tutur (lisan) yang hingga saat ini dianggap efektif. Pengetahuan kolektif Kalang yang berisikan sistem kepercayaan dan nilai-nilai budaya yang bersumber dari mitologi Kalang ditransmisikan dari generasi ke generasi melalui tradisi lisan sebagai strategi untuk menjaga kelangsungan hidupnya. Sistem kepercayaan Kalang berakar dari kesejarahan teologis yang berhubungan dengan agama Jawa purba yang bercorak animisme-dinamisme. Dalam perkembangannya, sistem kepercayaan dan nilai-nilai budaya Kalang mengalami dinamika sejalan masuknya agama-agama besar ke Jawa (Abdul, 2015).

Salah satu kelompok wong Kalang yang masih aktif melaksanakan tradisi obong dapat kita jumpai di Kabupaten Kendal. Kelompok wong Kalang ini merupakan kelompok yang dikenal dengan sebutan Demang Kalang. Demang (wedana/kepala distrik) merupakan pemimpin mereka pada masa lalu dan sangat dihormati. Kharisma yang muncul dari seorang Demang memberikan kekuatan spiritual untuk meneladani dan menghormati sosok pemimpin tersebut. Kelompok wong Kalang Kendal ini masih melaksanakan tradisi obong yang merupakan bentuk tanggung Jawab keluarga terhadap kerabat yang telah meninggal dunia.

Dalam kesehariannya, wong Demang Kalang (selanjutnya disebut wong Kalang) umumnya masih bermukim dalam arsitektur tradisional yang disebut rumah Limasan. Limasan menurut wong Kalang merupakan bentuk atap yang terdiri dari lima sap (bidang) atap. Dalam beberapa tulisan mengenai kawruh griya Jawa, juga dikenal atap Jawa Limasan yang merupakan kependekan dari kata Jawa limansap (Mangundarma, 1836) terjemahan (Yuniarto, 2012). Namun kesamaan antara keduanya apakah memiliki makna yang sama atau tidak perlu dikaji secara khusus. Kelompok wong Kalang bermukim dalam arsitektur Limasan memiliki dua tujuan utama yaitu sebagai ruang tempat melaksanakan aktivitas domestik dan juga sebagai ruang tempat aktivitas tradisi. Salah satu tradisi Kalang yang masih dilasanakan adalah tradisi Obong. Tradisi inilah yang dianggap sebagaian orang Jawa sebagai tradisi yang berbeda, namun banyak alasan mengapa tradisi obong ini masih terus dilaksanakan.

\section{Rumusan Masalah}

Dari pendahuluan yang telah diulas, maka ada beberapa hal yang penting terkait arsitektur tradisional Limasan dengan tradisi Kalang yaitu: 1) Arsitektur tradisional Jawa Limasan digunakan wong Kalang untuk aktivitas domestik dan tradisi; 2) Tradisi Kalang obong yang dilaksanakan dalam arsitektur Limasan ternyata dianggap tradisi yang berbeda dengan masyarakat Jawa; 3) Arsitektur Limasan yang digunakan kelompok wong Kalang merupakan salah satu bentuk atap bangunan Jawa, hal ini tentunya memiliki makna yang berbeda.

Dari beberapa hal yang telah dirumuskan diatas, maka ditemukan beberapa pertanyaan yang perlu dicari jawabannya yaitu: 1) Apakah arsitektur Limasan memiliki hubungan dengan tradisi obong yang dilaksanakan wong Kalang?; 2) Apa makna arsitektur Limasan bagi kelompok wong Kalang?

\section{Etnografi Sebagai Teknik Menemukan Masalah Penelitian Etnis}

Melalui peradigma deduktif dengan metode penelitian kualitatif, penelusuran tradisi Kalang obong dalam arsitektur Limasan menggunakan pendekatan etnografi. Pendekatan etnografi ini dianggap mampu menggambarkan aktivitas tradisi dan ritual yang jelas. Etnografi juga mampu mengungkap berbagai hal yang sifatnya eksplisit dan impisit yang ada dalam budaya. Pengungkapan implisit membutuhkan pengetahuan peneliti mengenai makna budaya secara khusus (Spradley, 1980). Pengetahuan khusus yang dimaksud merupakan bentuk partisipasi peneliti etnografi dalam lokus 
penelitian dan secara khusus pada unit amatan. Bukan sekedar mengamati, menggambarkan, menceritakan, namun lebih mendalam untuk dapat memahami gagasan, konsep dan filosofi yang terkandnung dalam budaya tersebut (Rapoport, 2005). Filosofi akan menyangkut semua aspek kehidupan kelompok masyarakat. Filosofi juga akan memberikan landasan dalam menyelesaikan masalah dalam etnis yang menyakininya (Rapoport, 1969). Pokok-pokok pemikiran etnografi ini menjadi dasar untuk menemukan makna arsitektur tradisional Limasan wong Kalang. Selain mengetahui filosofi dari tradisi kalang, perlu pula pemahaman mengenai teori-teori ikatan budaya yang terjadi dalam tradisi obong yang secara implisit menggunakan arsitektur Limasan.

Dari berbagai teori-teori ikatan budaya yang ditemukan dalam etnografi, dapat bermuara pada strategi untuk menemukan teori grounded. Bukan hanya untuk keperluan peneliti, namun dengan teknik etnografi memberi kejelasan kepada kelompok etnis untuk dapat menyelesaikan masalah melalui pemikiran sederhana dan logis sesuai realita kehidupan saat ini (Creswell, 2014). Penelitian ini secara spesifik melakukan pengamatan dan keterlibatan langsung dalam aktivitas tradisi obong. Untuk mencapai tujuan yang diharapkan, maka beberapa langkah dilakukan yaitu: 1) Penentuan informan dan unit penelitian melalui kriteria tertentu; 2) Pemahaman secara mendalam mengenai aktivitas budaya, tradisi dan ritual wong Kalang; 3) Terlibat aktif dalam aktivitas tradisi; 4) Memahami, mendalami dan merasakan suasana budaya yang ada dalam desa Kalang; 5) Keterlibatan dalam kehidupan wong Kalang dalam waktu yang cukup; 5) Keterlibatan yang tidak bersifat analitis agar tidak merubah suasana asli dan alami dalam tradisi Kalang. Dengan melakukan pendekatan etnografi dalam lingkup permukiman yang didasarkan pada kesamaan etnis, perubahan budaya terasa dinamis mengikuti perubahan pola kehidupan sosialnya. Aktivitas sosial akan membentuk ruang budaya, dan ruang budaya yang terbentuk dipengaruhi oleh aktivitas religi untuk etnis tertentu (Suprapti, 2010). Dengan demikian etnografi pada tradisi Kalang obong, perlu adanya pemahaman terkait aktivitas yang berkaitan dengan kepercayaan atau religi.

\section{Langkah-langkah Penelitian}

Grand tour, merupakan observasi awal yang dilakukan untuk menemukan benang merah dari berbagai sebaran etnis Kalang yang ada dipulau Jawa. Benang merah tersebut akan menunjukan adanya kesamaan tradisi yang dilakukan pada kelompok wong Kalang. Dari beberapa kelompok wong Kalang yang masih eksis meskipun hanya merupakan paguyuban (perkumpulan sosial) dapat diketahui aktivitas tradisi mereka. Grand tour dilakukan melalui dua tahap yaitu: 1) Observasi awal mengenai kesamaan tradisi dalam kehidupan sosial dan budaya. Observasi awal ini dilakukan di Kota Yogyakarta, Gombong, Solo dan Kendal. dari beberapa kota yang telah dilakukan observasi awal kemudian dipilih Kabupaten Kendal sebagai lokasi observasi berikutnya. Alasan pemilihan Kabupaten Kendal karena kelompok wong Kalang yang ada masih rutin melaksanakan beberapa tradisi Kalang yang diwarisi oleh leluhur mereka; 2) Observasi mengenai karakteristik tradisi meterial yang mereka gunakan untuk menunjang tradisi unmaterial. Ditemukan lokasi desa Kalang yang masih memegang teguh tradisi Kalang, suatu keunikan yang ditemukan adalah hunian mereka yang menempati arsitektur Limasan dan melaksanakan tradisi Kalang dalam ruang arsitektur Limasan.

Mini tour (observasi mendalam), dari observasi awal ditemukan arsitektur Limasan yang digunakan sebagai wadah (tempat) untuk malaksanakan tradisi Kalang. Observasi mendalam dilakukan terhadap aktivitas wong Kalang pada saat melaksanakan tradisi Obong. Kemudian menentuan unit penelitian berdasarkan tradisi yang sedang dilakukan, hal ini memungkinkan untuk mengamati langsung mengenai berbagai aktivitas tradisi Kalang terhadap ruang arsitektur Limasan. Digunakan teknik etnografi untuk mengetahui makna ruang pada arsitektur Limasan sebagai wadah tradisi obong". Observasi mendalam dilakukan melalui tahap-tahap sebagai berikut: Menentukan Informan Kunci, merupakan hal yang penting dalam penelitian kualitatif. Informan ditentukan dengan beberapa syarat yaitu: 1) Merupakan wong Kalang sejati maksudnya adalah wong Kalang yang memiliki orang tuanya keturunan Kalang asli; 2) Sejak lahir hidup di desa Kalang; 3) Masih melaksanakan tradisi Kalang.

Analisis Domain, menurut (Spradley, 1980) perlu melakukan beberapa langkah untuk mengetahui domain yang ada dalam tradisi agar mudah untuk mengklasifikasi, dengan cara: 1) 
Menemukan domain awal yang akan digunakan untuk menemukan sebutan domain yang telah umum digunakan; 2) Analisis domain yang telah ada dan mencari domain lain agar bisa digunakan untuk menemukan hipotesis lapangan; 3) Menyusun pertanyaan struktural untuk menemukan jawaban pertanyaan penelitian; 4) Melakukan analisis hubungan semantik dari berberapa hipotesis lapangan agar menemukan makna dari hubungan-hubungan yang ada dalam budaya. Dari empat langkah tersebut akan tersusun hubungan semantik dari domain yang ditemukan dalam beberapa sub domain yang memiliki peran dalam menentukan makna ruang dari tradisi Kalang di arsitektur limasan. Dari analisis domain ini akan dilakukan tahap selanjutnya adalah tahap analisis fokus dari beberapa data yang telah ditemukan dalam domain yang menunjukan hubungan antar aktivitas tradisi dengan ruang arsitektur Limasan.

Tahap selanjutnya adalah analisis taksonomi, merupakan pengelompokan dari beberapa kategori yang telah ditemukan dalam analisis domain dan telah dilakukan analisis fokus sehingga dapat terlihat dengan jelas kelompok yang memiliki kesamaan secara hirarki. Setelah tersusun dalam hirarki yang jelas dan menunjukan keeratan hubungan, kemudian dilakukan analisis dalam dua tahap yaitu: 1) Analisis observasi, pada tahap ini hal yang penting adalah saat melakukan wawancara. Makna dari berbagai istilah yang ditemukan saat wawancara akan terjawab dalam istilah-istilah. Istilah yang ditemukan akan mungkin sama dengan istilah yang umum digunakan atau mungkin berbeda; 2) Analisis komponen, adalah pencarian sistematis komponen makna yang menunjukan hubungan antara tradisi obong dengan ruang arsitektur Limasan. Observasi tematik, dilakukan dengan teknik deskripsi mendalam mengenai dua fokus penelitian yaitu: 1) Arsitektur Limasan ditinjau dari elemen-elemen arsitektur, ornamen, dan setting ruang arsitektur; 2) tradisi Kalang obong. Tema-tema akan berhubungan dengan fokus penelitian. Untuk mengetahui tema-tema yang muncul, dilakukan observasi melalui keterlibatan langsung peneliti dalam tradisi obong, wawancara dan pengambilan gambar/video untuk mengetahui tema-tema yang muncul. Pengelompokan data, dari hasil pengamatan dan keterlibatan dalam aktivitas tradisi, diperoleh gambaran yang jelas mengenai tradisi tersebut.

Gambaran siatuasi dan cerita mengenai tradisi tersebut akan dimasukan dalam kelompok tematema untuk tiap aktivitas. Pengelompokan ini terbagi dalam dua kategori utama yaitu arsitektur Limasan dan tradisi Kalang obong. Mengkonstruksi hasil - mengkaji setting (ruang Limasan dan ritual Kalang obong), setelah informasi yang dibutuhkan telah terpenuhi, kasus-kasus yang dibutuhkan telah cukup, maka langkah selanjutnya adalah mengkonstruksi hasil. Pada tahap ini, sketsa diagramatik yang menunjukan hubungan antara tema-tema dan sub tema dari masing masing kategori (arsitektur Limasan dan tradisi Kalang obong) merupakan alat bantu untuk menemukan tema-tema kajian yang akan menjadi konsep. Konsep dan simpulan ini akan ditemukan makna ruang arsitektur Limasan menurut kelompok wong Kalang.

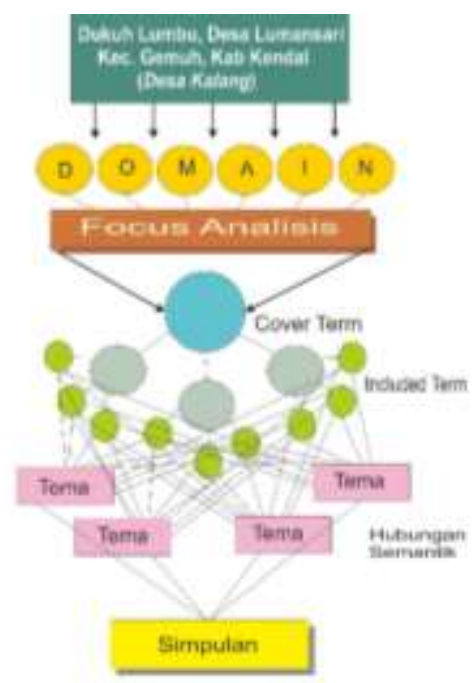

1 Research focus

1 Domain determination and domain analysis focus

1 Scope of activities of groups of Kalang people

1 Data found within the scope of the activity

1 Analysis of semantic relationships

6 Concepts / Conclusions

Gambar 1: Langkah Penelitian

Sumber: Prabani 2017 


\section{Lokus Penelitian Dukuh Lumbu, Desa Lumansari}

Dukuh Lumbu merupakan desa Kalang yang mayoritas $\pm 90 \%$ penduduknya adalah wong Kalang, terbanyak dibandingkan dukuh-dukuh lain yang juga merupakan desa (tempat, istilah Hindu Bali) Kalang yang ada di Kabupaten Kendal. Dengan status sebagai desa Kalang (desa yang didirikan oleh wong Kalang), semua tradisi Kalang dilaksanakan dalam lingkup desa tersebut. Batas lingkup desa Kalang merupakan batas tradisi Kalang, maksudnya adalah tradisi Kalang hanya dilakukan dalam lingkup desa tersebut, diluar desa tidak diperkenankan melakukan tradisi obong meskipun hanya dinding rumah yang menjadi batas desa Hal ini tentunya memiliki maksud yang baik, namun dalam bahasa wong Kalang hanya dikatakan "mboten ilok" (tidak baik). Sebagai masyarakat Jawa yang telah berbaur, wong Kalang masih memiliki "tepo seliro" (tenggang rasa) terhadap warga lain, demikian pula mereka terbuka dengan siapa saja yang ingin hidup berdampingan dalam desa Kalang.

Hal ini menunjukan keterbukaan orang Jawa terhadap siapa saja tanpa memandang perbedaan. Dukuh Lumbu merupakan sub wilayah yang ada di desa Lumansari, Kecamatan Gemuh, di Kabupaten Kendal-Jawa Tengah. Permukiman Dukuh Lumbu, desa Kalang masih melakukan tradisi Kalang Obong yang dilakukan pada pitung dino (tujuh hari) dan mendak setunggal (satu tahun) setelah meninggalnya kerabat wong Kalang. Dari beberapa tradisi yang dilaksanakan dalam dukuh Lumbu, dilaksanakan dalam arsitektur Limasan. Dari tradisi yang dilaksanakan dalam rumah Limasan tersebut, beberapa rumah dijadikan unit penelitian. Unit penelitian tersebut diamati secara mendalam dan mengikuti semua aktivitas ritual tradisi Obong. Beberapa kriteria penentuan unit penelitian ini antara lain: 1) Orientasi bangunan; 2) Jenis Kelamin orang yang meninggal; 3) Material rumah; 4) Posisi rumah; 5) Setting ruang.
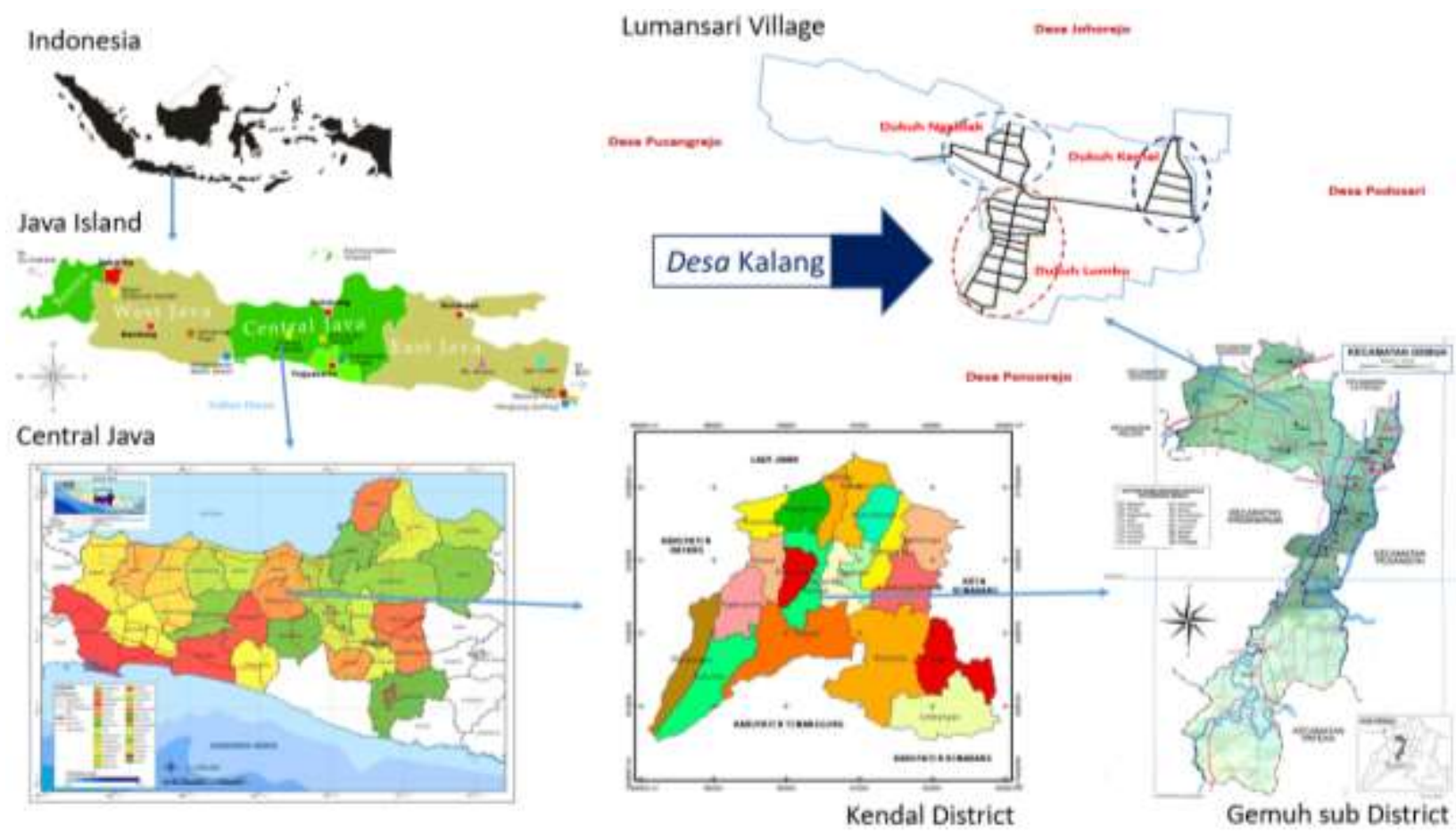

Gambar 2: Lokus Penelitian Sumber: Prabani 2017 


\section{Unit Penelitian}

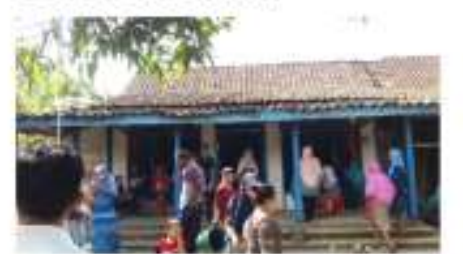

Rumah Mbah Sudar (aim), 7 hari, Selatan

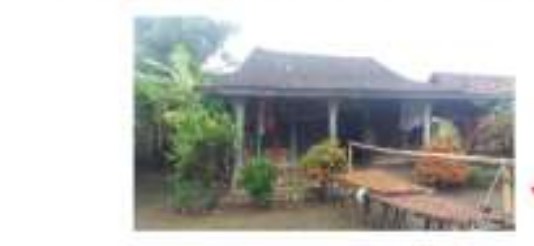

Rumah Mbah Kakung Tasrip (alm), Utara

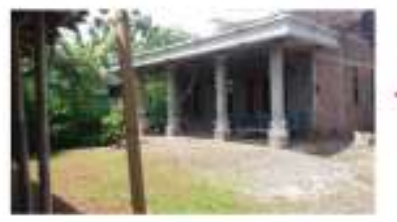

Rumah Bapak Sopyan (alm), Selatan

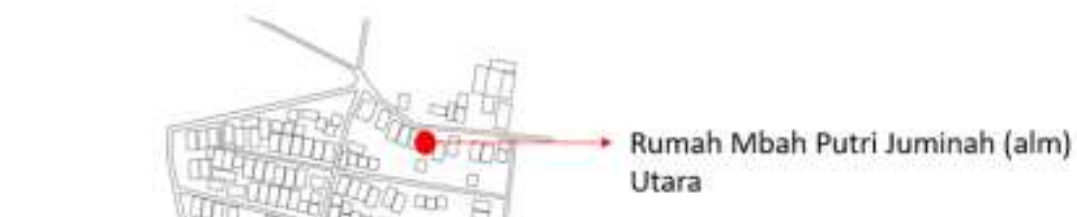

Utara
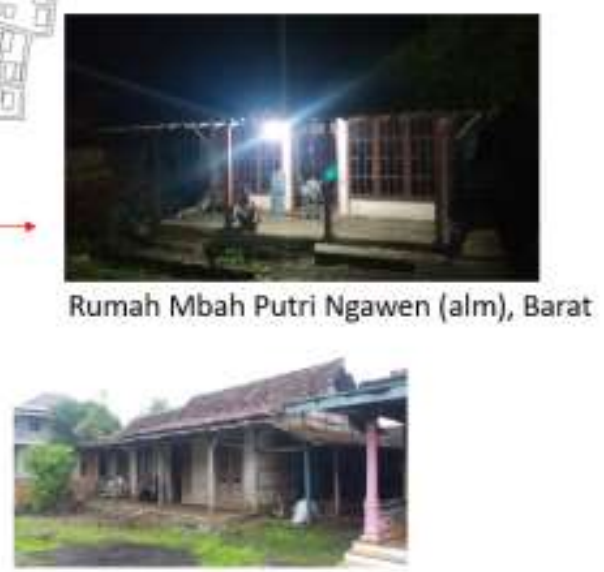

Rumah Mbah Putri Kasmiyah (alm), Selatan

Gambar 3: Unit Penelitian

Sumber: Prabani 2017

\section{Struktur dan Ruang Arsitektur Limasan}

Wong Kalang merasa nyaman hidup dalam rumah Limasan, hal itu terungkap dalam beberapa ungkapan warga yang ada di Dukuh Lumbu, Desa Lumansari. Mayoritas hunian yang ada berjenis Limasan (varian Limasan). Secara umum ada dua jenis variasi arsitektur Limasan yang dapat dijumpai. Pertama adalah arsitektur Limasan, yang disebut juga atap omah (rumah) Limasan. Sedangkan kedua adalah bentuk Limasan Grojogan, yang disebut omah Grojogan merupakan variasi atap limasan yang memiliki bumbungan atap lurus tanpa ada sudut tekukan miring disisi kanankirinya. Secara struktur bangunan, juga ditemukan dua jenis struktur rangka bangunan yang menopang atap Limasan. Pertama adalah rangka bangunan yang memiliki tungko/soko guru (empat tiang utama) sebagai penopang inti bangunan dan dikelilingi oleh tiang kayu pengapit . Tungko/sokoguru yang ditemukan bervariasi pada sistem sambungan atas (tumpangsari), yaitu balok penyatu sederhana, balok penyatu tunggal, dan balok penyatu tumpuk/ganda. Pada balok penyatu sederhana menggunakan konstruksi sederhana dengan penguat balok siku pada stungko/soko-guru dan balok atas; balok penyatu tunggal menggunakan teknik sambungan pasak dan lubang yang menyatukan keempat tungko/soko-guru dan hanya dikunci dengan pasak melintang; sedangkan balok penyatu tumpuk/ganda merupakan struktur penyatu soko-guru dengan teknik sambungan kayu yang tersusun dan saling mengunci. Struktur bangunan Limasan kedua yang ada adalah struktur tiang yang terbagi rata dalam empat baris membujur dan melintang, membentuk empat persegi baik melebar kesamping, melebar kebelakang atau membentuk bujur-sagkar. Ruang yang terbentuk dibawah atap Limasan dan Grojogan merupakan ruang kosong yang ditutup dengan dinding blabak (papan kayu). Pada sisi depan terdapat tiga pintu dengan tiap bukaan memiliki dua daun pintu, sisi belakang umumnya terdapat satu pintu, dan pada sisi samping kanan-kiri hanya terdapat jendela. Pembagian ruang arsitektur Limasan, setting ruang mengikuti tradisi Kalang yang berhubungan dengan kosmologi, gender, fungsi ruang, hirarki ruang, posisi anggota keluarga, dan masih banyak tradisi tata ruang yang mengaturnya. 


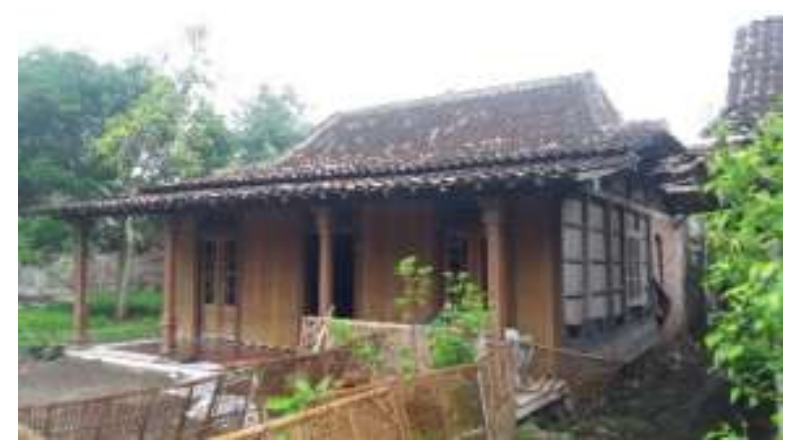

Gambar 4: Arsitektur Limasan

Sumber: Prabani 2017

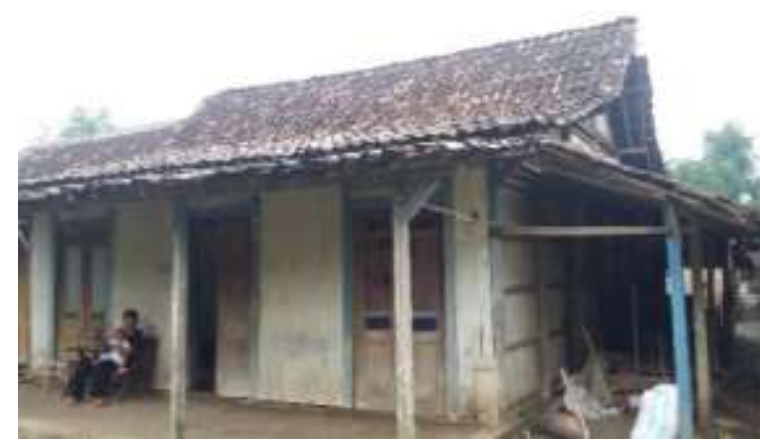

Gambar 5: Arsitektur Limasan Grojogan Sumber: Prabani 2017
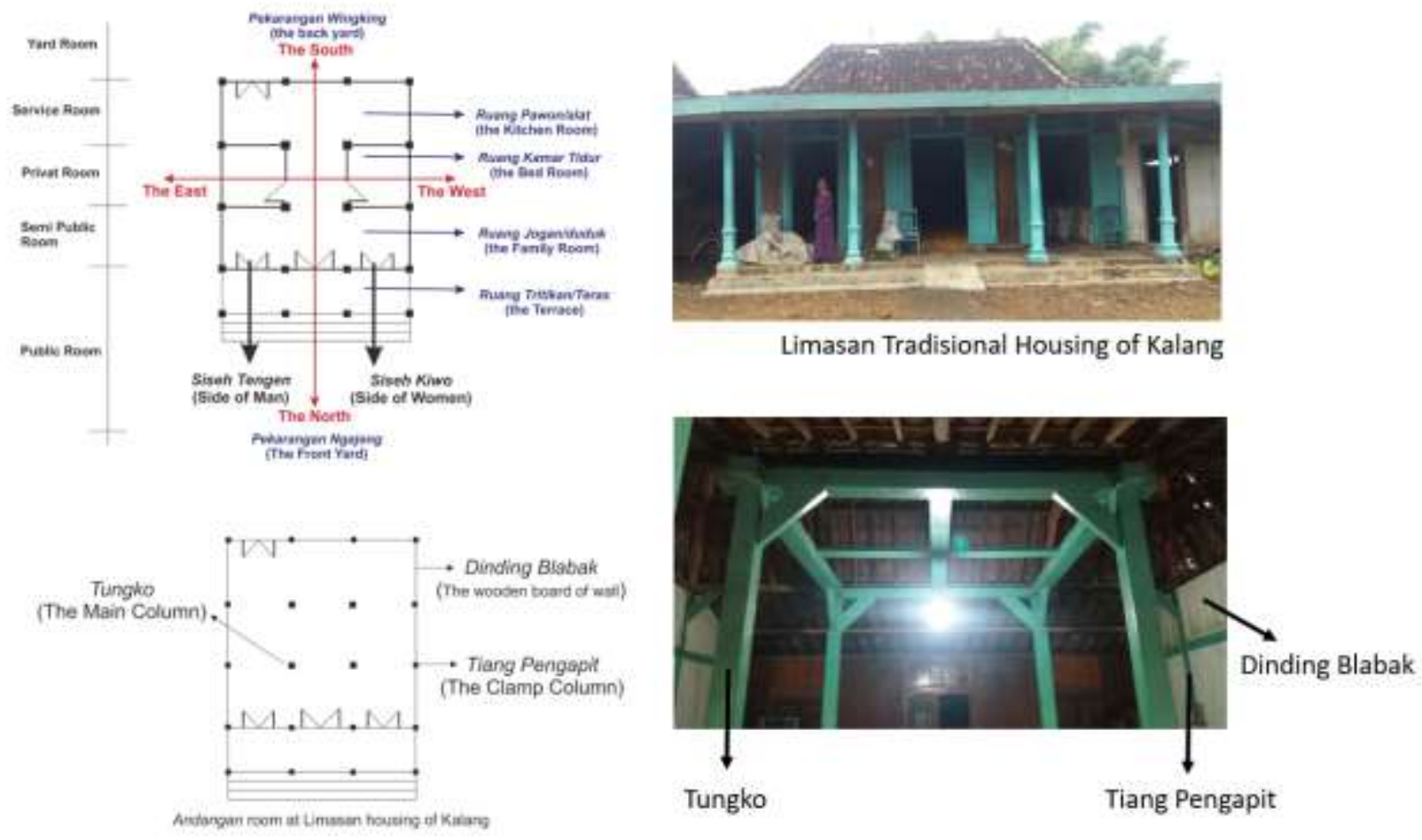

Gambar 6: Denah dan Struktur Limasan Kalang Sumber: Prabani 2017

\section{Tradisi Kalang Obong sebagai tanggung Jawab Keluarga}

Wong Kalang secara historis selalu hidup dalam tradisi yang ditransmisikan melalui narasi turun-temurun diterima oleh anggota kelompoknya, secara khusus adalah keturunan wong Kalang. Narasi merupakan suatu cara yang disampaikan dalam suatu kelompok dengan tujuannya untuk meneruskan identitas, menjaga budaya dan mengembalikan ingatan kepada sesuatu yang telah ada sebelum mereka ada (Jeanette \& Fortier, 2007). Dalam tradisi Kalang mengingatkan anggota kelompoknya untuk tetap mengenang leluhur yang telah ada sebelumnya, menghargai dan memberikan penghormatan melalui ritual-ritual yang mereka jalankan. Kepatuhan wong Kalang 
merupakan teladan bagaimana orang Jawa patuh dan taat pada tradisi. Tradisi Kalang menyeluruh pada aspek kehidupan wong Kalang baik tradisi yang menghasilkan material maupun unmaterial.

Proses transfer pengetahuan tradisional dilakukan melalui lisan maupun tulisan. Wong Kalang membangun identitas budayanya berdasarkan nilai-nilai yang diwarisi dari leluhurnya (Abdul, 2015). Kalang adalah tradisi, begitulah yang mereka katakan saat orang menanyakan apakah Kalang itu? Tradisi yang dilakukan antara lain adalah tradisi obong. Tradisi Obong ini banyak dikenal oleh warga lain yang ada di Kabupaten Kendal, Kotagede Yogyakarta, dan beberapa daerah yang berada di ex Karesidenan Banyumas. Bentuk tradisi ini diakui oleh orang Kalang hampir sama dengan tradisi ngaben di Bali. Tradisi obong dilaksanakan dalam dua waktu yaitu pertama pitung dino (tujuh hari) setelah meninggal dunia. Pada saat pitung dino ini keluarga membakar sandangan yang dimiliki dan yang pernah digunakan oleh almarhum/almarhumah, selain itu berbagai sangu (bekal) berupa bahan makanan, buah, nasi kluban, lauk-pauk dan uang. Tradisi tersebut dilaksanakan pada siang hari setelah pukul 12.00 diawali dengan ritual obong yang dipandu oleh dukun sonteng (dukun Kalang yang memandu ritual), dilaksanakan dalam ruang rumah Limasan. Setelah ritual tersebut kira-kira pukul 13.00 dilakukan ritual obong yang dilaksanakan di pekarangan ngajeng (halaman depan rumah). Dalam tradisi ini posisi ritual berada pada satu garis lurus disisi kiri rumah Limasan. Tradisi obong kedua dilaksanakan pada waktu mendak setunggal (satu tahun) setelah meninggal. Tradisi ini memiliki beberapa tingkatan ritual yang dapat dilaksanakan dengan pertimbangan ekonomi masingmasing keluarga. Tradisi obong yang besar dilaksanakan dengan diawali pemotongan kerbau jantan.

Dalam tradisi pemotongan kerbau ini, kerbau yang telah dipotong akan dikuliti untuk diambil dagingnya dan dimasak sedangkan kulit, kaki, kepala dan ekor dipisahkan yang kemudian akan disatukan lagi untuk ritual slemetan (doa keselametan) sebelum tradisi obong. Dukun sonteng akan menyiapkan berbagai sesaji untuk diletakan dalam ruang kiwo (yang tidak mengganggu aktivitas lain) disiapkan untuk menidurkan ngantenan (boneka kayu) yang akan dikeluarkan pada pukul 20.00 saat dilakukan ritual teng-teng (suara teng-teng saat pembacaan mantra dari alat pertanian logam).

Kemudian dilakukan ritual angon/giring kerbau (mengembala kerbau), dengan pembacaan mantra (doa) dan diakhiri dengan ritual nyangoni (memberi bekal) baik dari pihak keluarga berupa uang dan dibalas oleh melalui dukun sonteng dengan memberi makanan kepada sanak saudara. Selesai ritual tersebut semua perlengkapan ritual teng-teng dikembalikan ke ruang kiwo lagi untuk beristirahat, namun ada juga yang lek-lekan (tidak tidur). Pada pukul 03.00, semua keluarga bangun, dukun sonteng menyiapkan lagi semua oborampe sesaji dan ngantenan untuk dilakukan ritual serupa seperti ritual sebelumnya pada pukul 20.00 dan dilanjutkan dengan ritual obong semua sesaji, ngantenan, sandangan dan sangu, yang diletakan dalam omah-omahan berbahan alang-alang (rumput). Sebelum dilakukan obong, masih ada ritual kecil mengelilingi omah-omahan sebelum dibakar. Sampailah pada ritual pembakaran hingga habis menjadi abu. Ritual terakhir adalah melemparkan uang koin untuk diperebutkan oleh semua orang yang hadir. Tradisi ini menurut dukun sonteng Mak Wariah dan Mak Kubro , mak Wanti (Almarhumah) (2017), merupakan tradisi yang muncul pada jaman kerajaan Hindu di pulau Jawa. Tradisi ini merupakan tradisi besar yang dilaksanakan oleh keluarga besar yang melibatkan tetangga dan lingkungan sekitar desa Kalang. 


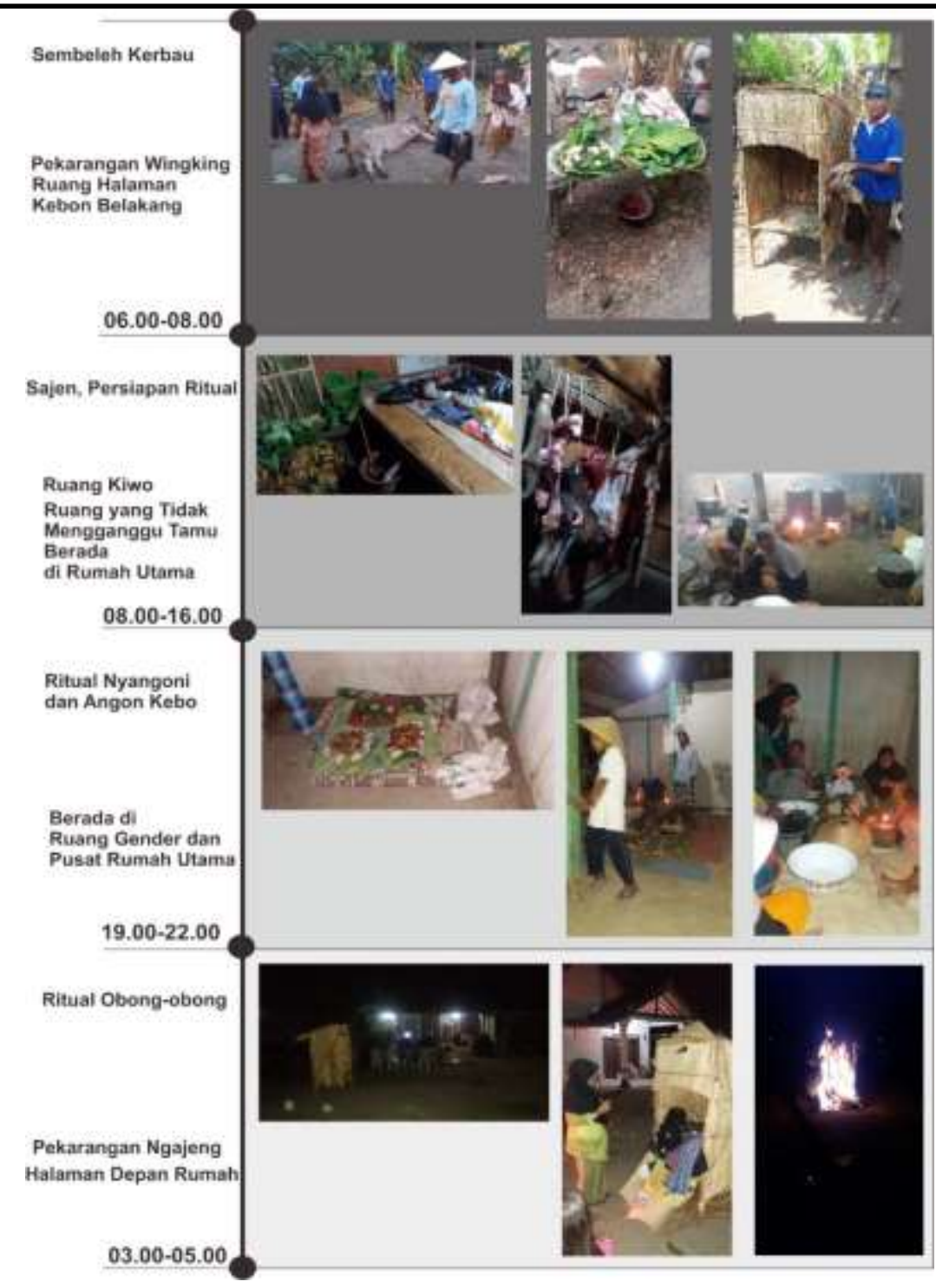

Gambar 7: Pelaksanaan Tradisi Obong Sumber: Prabani 2017

\section{Diskusi}

Hubungan antara elemen-elemen arsitektur Limasan dengan tradisi Kalang obong.

Ruang dibawah atap Limasan memiliki hubungan dengan tradisi Kalang obong. Dibawah atap Limasan terbentuk sembilan petak ruang arsitektur yang dibatasi tiang kolom. Ruang tersebut terbagi simetris secara membujur serta melintang dan terpusat pada satu titik ruang ditengah. Sembilan (sanga) menunjukan petungan tertinggi dan merupakan angka baik dalam Jawa yang juga diyakini oleh wong Kalang. Ruang yang terbentuk simetris membujur dari pekarangan ngajeng (depan) ke pekarangan wingking (belakang) digunakan oleh tradisi Kalang obong untuk memposisikan ritual obong sebagai tempat ritual pada sisi kiwo (kiri). Sedangkan pembagian melintang dari sisi tengen (kanan) ke sisi kiwo (kiri) dan terpusat pada tungko/sokoguru. Pembagian membujur ini membagi ruang menjadi empat ruang yaitu: pekarangan ngajeng (halaman depan), teras, ruang andangan Limasan, dan pekarangan wingking (halaman belakang). Ruang Andangan Limasan merupakan ruang kosong dari arsitektur Limasan. Ruang andangan ini akan dibentuk ruang-ruang kecil sebagai ruang fungsional. Dikatakan fungsional karena ruang yang disusun mengikuti kebutuhan dan tradisi fungsi ruang arsitektur Limasan Kalang.

Dengan pembagian dua ruang kiwo-tengen, orang tua-anak, lanang-wedhok menjadi dasar pembentukan ruang. Sedangkan jika kita merujuk pada pendapat Tjahjono (1989), bahwa tata ruang rumah Jawa Joglo atau Limasan terbagi menjadi dua bagian yaitu: bagian depan digunakan sebagai 
ruang semi publik yaitu ruang yang digunakan untuk aktivitas yang bersifat sosial dengan kerabat atau tetangga yang telah dikenal dekat. Aktivitas yang bersifat sosial ini dikenal dengan ruang omah jero. Ruang omah jero (ruang dalam rumah utama) suatu ruang yang dalam rumah Jawa memiliki posisi didepan dari rumah utama. omah jero lebih banyak digunakan untuk aktivitas sosial dan pertemuan kerabat atau tamu yang sudah dikenal. Sedangkan bagian kedua adalah senthong yang dibagi menjadi tiga ruang yaitu senthong tengen, senthong tengah dan sentong kiwo.

Lain halnya dengan rumah Jawa yang terbagi menjadi tiga ruang. Pembagian tiga dikarenakan ada empat tiang utama yang merupakan sokoguru dan dua belas tiang pengapit yang berada di sisi luar sokoguru. Akibatnya terbentuklah tiga ruang yang melebar dari sisi depan, sisi tengah dan sisi belakang. Posisi senthong menempati sisi ruang paling belakang/paling dalam pada. Pembagian pekarangan Jawa dengan pembagian pekarangan Kalang tidak berbeda yaitu: pekarangan ngajeng, omah dalem, pekarangan wingking. Sedangkan fungsi dari pembagian tersebut berbeda. Dalam satu ruang arsitektur terdapat elemen-elemen arsitektur dan konstruksi, Rapoport (1969) mengatakan bahwa arsitektur akan terbentuk melalui faktor sosial budaya yang melekat dalam kelompok etnis tertentu. Nilai-nilai yang terkandung dalam kelompok etnis akan terkandung dalam wujud arsitekturnya. Nilai-nilai yang terkandung dalam arsitektur akan menuntun manusia untuk memandang dan memahami lingkungan sosial dan lingkungan alam disekitarnya.

Sedangkan hal-hal di luar tradisi yang sifatnya mendukung dan melengkapi terbentuknya arsitektur tradisional. Dalam arsitektur limasan wong Kalang, sisi kiwo (kiri) dan sisi tengen (kanan) berhubungan dengan ruang gender. Kiwo untuk perempuan dan tengen untuk laki-laki. Dalam tata ruang Jawa dijumpai pula ruang gandhog kiwo difungsikan untuk ruang anak, keluarga atau tamu perempuan, sedangkan ruang gandhog tengen yang difungsikan untuk ruang anak, keluarga atau tamu laki-laki. Konsep ini mengungkapkan bahwa diantara dua hal yang saling bertolak belakang terdapat suatu titik yang menghubungkan dua kehidupan yang disebut sebagai center (Tjahjono, 1989).

Demikian pula kosmologi Jawa yang menunjuk pada empat arah mata angin Utara, Selatan, Timur dan Barat yang dikenal dengan mancapat ditambah satu pusat/center merupakan titik tengah dari pertemuan garis bujur dan melintang dari mancapat. Dalam tradisi Kalang obong alur horisontal dalam tata ruang menjadi suatu alur sirkulasi dari ruang gelap (ruang wingking) menuju ruang terang (ruang ngajeng). Ruang gelap merupakan ruang mantenan tempat diletakan boneka kayu sebagai simbol raga kerabat yang telah meninggal. Sedangkan ruang terang berada pekarangan ngajeng (halaman depan) sebagai tempat membagar mantenan, sesaji dan sangu berupa sandangan dan perlengkapan lainnya. Mengantar arwah menuju nirwana dilakukan dalam ruang terang yang merupakan simbol hubungan dengan alam. Hal ini menunjukan bahwa dalam alam terbuka, segala arah dapat dicapai menuju nirwana. Pengembaraan di bumi dilambangkan dengan arsitektur tradisional Limasan yang diatur dalam tradisi. Elemen tiang kayu pada arsitektur Limasan menjadi batas nyata adanya pembagian ruang. Bentuk grid yang tersusun memberikan pola ruang diantara elemen-elemen bangunannya.

\section{Hubungan antara setting ruang arsitektur Limasan dengan tradisi Kalang obong.}

Beberapa domain yang ada memiliki hubungan seperti ruang kiwo, merupakan ruang yang dalam tradisi Kalang dimaknai sebagai ruang yang tidak mengganggu atau tidak diganggu oleh aktivitas manusia baik keluarga maupun para tamu yang berkunjung saat tradisi dilaksanakan. Ruang kiwo tersebut membujur dari ruang wingking (belakang) sampai di ruang pekarangan ngajeng (halaman depan) dari rumah inti. Fungsi dari ruang kiwo ini adalah untuk meletakan sajen (sesaji), menidurkan manten (boneka kayu) dan semua ubo-rampe (perlengkapan) berupa sandang dan bekal lain yang sifatnya duniawi, dan sebagai ruang ritual yang dipimpin oleh dukun sonteng. Ruang kiwo ini dalam domain arsitektur Limasan andangan Kalang merupakan kosmologi Jawa yang selalu memiliki padanan setara yang bertolak belakang seperti kiwo-tengen, lanang-wedok, sakral-profan, ngajeng-wingking, terang-gelap (Ronald, 1988). Dalam tradisi Kalang Obong beberapa ruang dalam sisi kiwo arsitektur Limasan digunakan sebagai: ruang mantenan (ruang membaringkan boneka kayu simbul raga dan sesaji), ruang ritual pembacaan mantra/doa, dan ruang obong (bakar). Dengan melihat letak ruang kiwo yang berurutan dari belakang menuju ke pekarangan ngajeng, maka 
merupakan ruang gelap yang umumnya hanya dapat dijangkau oleh orang tertentu khususnya penghuni rumah.

Demikian pula Tjahjono (1989) menjelaskan gradasi cahaya dari ruang arsitektur Jawa yang berturut-turut dari pekarangan ngajeng (depan) makin kebelakang (wingking) semakin gelap gradasi cahayanya. Dalam konteks tradisi Kalang obong gradasi cahaya dalam ruang terang dan gelap juga menunjukan ruang yang sama dari depan dan kebelakang semakin gelap. Gradasi cahaya gelap menuju terang tersebut dalam tiap aktivitas ritual ditunjukan dengan suasana yang berbeda. Perbedaan suasana tersebut menunjukan aktivitas kehidupan dan perjalanan manusia menuju nirwana.

\section{Hubungan antara Ruang Andangan arsitektur Limasan dengan tradisi Kalang obong.}

Ruang arsitektur merupakan ruang yang memiliki batas yang nampak, secara fisik dapat diketahui batasnya. Ruang tersebut memberikan ruang gerak bagi manusia untuk beraktivitas. Dengan demikian ruang arsitektur adalah bagian dari hidup manusia yang memberikan kepastian untuk beraktivitas. Ber-arsitektur artinya berinteraksi dan berkomunikasi dengan ruang. Demikian pula gatra sebagai unsur-unsur pelengkap ruang memberikan makna lebih terhadap arsitektur (Mangunwijaya, 1995). Komunikasi dengan ruang dalam tradisi Kalang obong menunjukan ketaatan wong Kalang terhadap tradisi yang telah diwariskan. Komunikasi tersebut secara sadar dipahami oleh mereka sebagai keharusan untuk melaksanakan dan mengakui kesalahan dalam pemindahan ruang sehingga diperlukan ritual tertentu. Ritual "jawab" tersebut akan dilakukan oleh dukun sonteng melalui komunikasi batin. Ritual tersebut pada intinya memohon ijin kepada leluhur dan kepada arwah kerabat yang akan di obong. Ritual "jawab" merupakan bentuk komunikasi dengan ruang tradisi. Ber-arsitektur selanjutnya berhubungan dengan guna/fungsi, menunjukan hal penting dalam ruang arsitektur. Fungsi ruang menjadi hal yang penting dalam tradisi Kalang. Ruang kiwo memiiliki makna bagi mereka yang telah meninggal dalam kepercayaan Kalang. Sedangkan fungsi ruang tengen sebagai ruang hidup dan masa depan. Ber-arsitektur menunjukan citra memberikan makna yang mendalam pada folosofi ruang yang diyakini wong Kalang sebagi hasil pemikiran mendalam untuk memisahkan ruang kematian dengan ruang lain yang merupakan kehidupan. Citra arsitektur limasan Kalang dalam ruang andangan (ruang dalam rumah limasan Kalang) menunjukan pengetahuan kosmologi ruang yang sudah memisahkan dua unsur yang saling bertolak belakang.

Dalam tradisi Kalang obong, ruang menjadi suatu yang penting dalam pelaksanaan ritual. Penentuan ruang menjadi hal yang penting sebelum semua ritual dilaksanakan, mulai dari perletakan sajen (sesaji) sebagai syarat mohon restu kepada yang menguasai alam semesta, perletakan mantenan (boneka kayu) serta berbagai uborampe untuk perlengkapan ritual. Posisi dukun sonteng saat ritual pun menjadi pemikiran awal sebelum semuanya terlaksana hingga pekarangan depan tempat pelepasan segala hal duniawi melalui pembakaran mantenan, omah-omahan dan uborampe yang disertakan sebagai bekal menuju nirwana. Ruang-ruang yang disiapkan sesungguhnya merupakan ruang simbolik yang berhubungan dengan tradisi, demikian pula hubungannya dengan ruang arsitektur Limasan yang memiliki filosofi Jawa yang simetris, menerus pada ruang sisi kiwo (kiri) arsitektur Limasan. Hal ini dapat sesuai dengan ruang simbolik yang dikatakan (Cassirer, 1987). Melalui proses berpikir yang sukar dan amat kompleks, manusia sampai pada idea tentang ruang abstrak. Dalam ruang abstrak, tidak berurusan dengan benda, melainkan dengan kebenaran pernyataan dan keputusan. Sirkulasi yang menerus dari ruang wingking yang gelap melintas lurus menembus ruang tengah menuju pekarangan ngajeng yang terang. Pikiran tentang ruang, waktu dan gerak hanya berdasar prinsip relasi yang memiliki makna.

Tradisi Kalang obong membutuhkan ruang yang mampu menampung kerabat dan tetangga yang secara khusus akan nyangoni (memberi bekal) kepada arwah orang yang talah meninggal. Konsep ruang dalam konteks tradisi Kalang dipengaruhi oleh kepercayaan terdahulu. Warisan tradisi tersebut secara nyata dalam kehidupan menunjukan suatu tempat (place) dan telah ditentukan ciri- 
ciri fisik, tata atur, persyaratan ruang, posisi ruang, hubungan antar ruang. Warisan leluhur terhadap ruang arsitektur menunjukan arsitektur Limasan Kalang muncul dari budaya tradisional kelompok etnis tertentu. (Tjahjono, 2002). Selanjutnya dikatakan bahwa melalui bentuk dan setting ruang arsitektur berhubungan dengan tempat. Tempat menjadi lokal budaya yang akan berkembang mengikuti perkembangan pergerakan sosial ekonomi manusia. Namun perkembangan tersebut akan tetap dikenali karena terkait dengan beberapa budaya dan memiliki makna. Makna tersebut merupakan kesepakatan budaya dan menjadi identitas. Identitas yang berakar pada budaya menjadi warisan budaya. Keberadaan setting ruang arsitektur Limasan Kalang memiliki makna yang sulit untuk berubah karena berakar dari nilai-nilai, tradisi dan budaya. Jika dibandingkan dengan fasade, sangat mudah untuk berubah. Perubahan yang terjadi pada arsitektur banyak didasari oleh perubahan sosial-ekonomi pemilik. Perubahan fasade ini merupakan bagian dari perubahan individu yang kadar tradisinya mulai pudar atau dipengaruhi oleh budaya lain yang dianggap lebih baik. Selain itu, ada pula perubahan fasade yang didasari oleh ketidak-pahaman pemilik terhadap makna tradisi. (Suprapti, 2014). Arsitektur tradisional dalam wilayah tertentu memiliki hubungan dengan lingkungan makronya. Lingkungan makro tersebut tentunya merupakan lingkup terkecil dibandingkan lingkup wilayah yang lebih besar. Lingkup makro dari arsitektur tradisional adalah desa/dukuh yang memiliki administrasi tradisional maupun administrasi pemerintahan. Administrasi tradisional akan mengatur pelaksanaan tradisi yang masih dilakukan oleh warganya. Desa Kalang menjalankan administrasi tradisional dan mengatur pelaksanaan tradisi warganya. Selain itu menerima wong Kalang lain yang ada diluar desa Kalang yang akan melaksanakan tradisi. Dengan demikian arsitektur Limasan adalah omah tradisi, dan desa Kalang adalah batas pelaksanaan tradisi (Prabani, Sugiono, 2018).

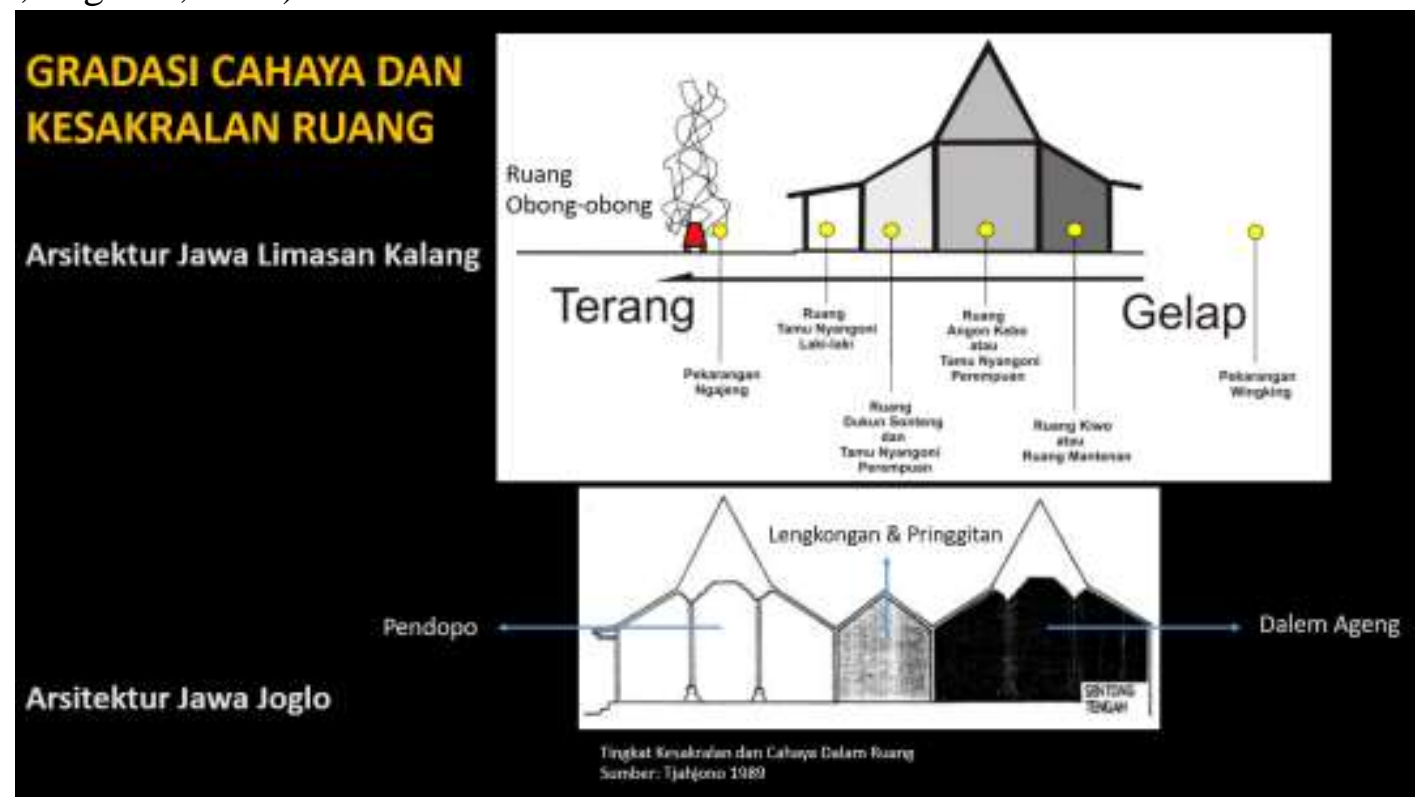

Gambar 6: Ruang Terang dan Gelap dalam tradisi Kalang Obong Sumber: Prabani 2018

\section{Simpulan}

Tradisi Kalang merupakan tradisi sub etnis Jawa yang memanfaatkan ruang arsitektur Limasan sebagai wadah (ruang) untuk melaksanakan ritual tradisi obong. Tradisi Kalang obong merupakan salah satu tradisi yang dilaksanakan kelompok wong Kalang sebagai pewaris tradisi Kalang. (Jocelyn, 1983) yang melihat tradisi sebagai model dari kehidupan masa lalu yang secara sadar digunakan oleh masyarakat untuk mengkonstruksi identitas mereka. sebagai suatu identitas, ternyata memiliki hubungan dengan etnis induknya (Jawa) dalam budaya ber-wujud yaitu arsitektur tradisional Limasan. Dengan demikian dapat disimpulkan: 1) Setting ruang arsitektur Limasan memiliki hubungan dengan tradisi Kalang. Setting ruang tersebut diwariskan menunjuk pada tempat, guna dan 
fungsi; 2) Arsitektur Limasan, memiliki makna yang penting dalam terlaksananya tradisi Kalang obong. Secara khusus pembagian ruang andangan pada arsitektur Limasan mengakomodasi ritual dalam tradisi Kalang.

Secara keseluruhan bukan hanya tradisi obong yang diakomdasikan oleh arsitektur Limasan tetapi ada kemungkinan tradisi Kalang lain yang juga diakomodasi. Selain itu perlu ditelusuri lagi tradisi dalam membangun arsitektur Limasan dengan budaya Kalang.

\section{Referensi}

Abdul, K. (2015). Pendidikan Agam Islam Dalam Kebudayaan Masyarakat Kalang. Jurnal AtTagaddum, Vol.7(2), 327-345. Retrieved from http://journal.walisongo.ac.id/index.php/ attaqaddum/article/view/1210/953

Cassirer, E. (1987). Manusia dan kebudayaan: Sebuah Esei Tentang Manusia. Jakarta: PT. Gramedia (terjemahan).

Creswell, J. . (2014). Research design pendekatan kualitatif, kuantitatif, dan mixed. Yogyakarta: Pustaka Pelajar.

Dakung, S. (1982). Arsitektur Tradisional Daerah Istimewa Yogyakarta. Yogyakarta: Depdikbud.

Djulianto, S. (2017). Menggali Nilai-nilai Budaya Dalam Prasasti Harinjing (804-927 Masehi). Majalah Archeologi Indonesia.

Jeanette \& Fortier. (2007). Cultural Memory, Resistance, faith and identity. University of Texas Press.

Jocelyn, linnekin. (1983). Defining Tradition: Variations on the Hawaiian Identity. American Ethnologiest Journal, vol.10(no.2), 241-252.

Lombard, D. (2005). Nusa Jawa: Silang Budaya, Warisan Kerajaan-Kerajaan konsentris. Jakarta: Gramedia Pustaka Utama.

Mangundarma. (1836). Serat Kawruh Griya, Serat Kawruh Kalang. Surakarta: Keraton Surakarta.

Mangunwijaya, Y. . (1995). Wastu Citra. Jakarta: PT.Gramedia Pustaka Utama.

Muhammad, S. (2010). Ritual dan tradisi Islam Jawa. Yogyakarta: Narasi.

Prabani, Sugiono, A. (2018). OMAH KALANG OMAH TRADISI, DESA KALANG DESA TRADISI (Etnografi Tradisi Sub Etnis Jawa, Kalang). Jurnal Arsitektur ARCADE, Vol.2(no.2), 79-87.

Ranggawarsita, W. (2007). Kamus Kawi-Jawa. Yogyakarta: Gajah Mada University Press.

Rapoport, A. (1969). House Form and Culture. London: Prentice Hall.

Rapoport, A. (2005). Culture, Design and Architecture. Locke Science. Chicago: Locke Science Publishing Company, Inc.

Revianto, S. B. (2000). Omah, Menbaca Makna Rumah Jawa. Yogyakarta: Yayasan Bentang Budaya. Ronald, A. (1988). Manusia dan Rumah Jawa. Yogyakarta: Juta.

Spradley, J. . (1980). The Participation Observation. New York: Reinhart \& Winston.

Suprapti, A. (2010). Etnography-Architecture in Kampong Kauman Semarang: A Comprehension of Cultural Toward Space. American Journal of Engineering and Applied Sciences, Vol.3(no.3), $576-587$.

Suprapti, A. (2014). THE TRADITION OF LIVING OF MUSLIM COMMUNITY KUDUSKULON. Journal of Social Sciences, vol.10(no.2), 63-73.

Suseno, M. (1984). Etika Jawa. Jakarta: Gramedia Pustaka Utama.

Tjahjono, G. (1989). Cosmos, Centre and Duality in Javanese Architectural Tradition: The Symbolic Dimension of House Shapes in Kota Gede and Surrounding. University of California.

Tjahjono, G. (2002). Arsitektur: Indonesian Heritage. Jakarta: PT.Widyadara.

Yuniarto, D. (2012). Kajian Filologi dan Isi Dalam Serat Kawruh Griya. Yogyakarta: Fakultas Bahasa dan Seni UNJ, Skripsi. 